\title{
Mutation rates at the glycophorin A and HPRT loci in uranium miners exposed to radon progeny
}

\author{
E M Shanahan, D Peterson, D Roxby, J Quintana, A A Morley, A Woodward
}

\begin{abstract}
Objectives-To find whether a relation exists between estimated levels of exposure to radon and its progeny and mutations in hypoxanthine phosphoribosyl transferase (HPRT) and glycophorin $A$ in a cohort of former uranium miners.

Methods-A cohort study involving a sample of miners from the Radium Hill uranium mine in South Australia, which operated from 1952 to 1961. Radiation exposures underground at Radium Hill were estimated from historical radon gas measures with a job exposure matrix. Workers from the mine who worked exclusively above ground according to mine records were selected as controls. In 1991-2 miners were interviewed and blood taken for measurement of somatic mutations. Mutation rates for HPRT and glycophorin A were estimated with standard assay techniques.
\end{abstract}

Results-Homozygous mutations of glycophorin $A$ were increased in underground miners $(P=0.0027)$ and the mutation rate tended to rise with increasing exposure with the exception of the highest exposure $(>10$ working level months). However, there was no association between place of work and either the hemizygous mutations of glycophorin A or the HPRT mutation.

Conclusions-There may be an association between glycophorin A mutations and previous occupational exposure to ionising radiation. However, not enough is known at present to use these assays as biomarkers for historical exposure in underground mining cohorts.

(Occup Environ Med 1996;53:439-444)

Keywords: uranium miners; glycophorin A; HPRT; radon progeny

There is currently great interest in the role of somatic mutations as potential biomarkers for radiation exposure. Identification of biomarkers may lead to: (a) more valid and precise classification of exposure to radiation in humans; (b) a better understanding of radiation effects on incidence of disease at low doses (thereby allowing for more accurate standard setting); (c) better screening tools for early carcinogenic or precarcinogenic effects, with the potential for earlier intervention and improved health outcomes in early carcino- genic cases, or prevention strategies in precarcinogenic cases; $(d)$ improved understanding of the process of carcinogenesis in humans. ${ }^{1}$

According to some authors, the combination of central effects and precision of measurement make genetically based radiation dosimetry a unique tool for cancer prevention. ${ }^{2}$ Others suggest that exposures to environmental mutagens are unlikely to be sufficiently large to allow interpretation of mutation rates in individual men to be meaningful. They argue that the main role of these assays will be to facilitate the study of the biological process of mutagenesis and carcinogenesis. ${ }^{3}$ All agree that the assays require further study in a variety of populations.

Two of the most promising mutation assays seem to be the hypoxanthine phosphoribosyltransferase (HPRT) assay and the glycophorin A (GPA) assay. The HPRT assay identifies mutations at the $\mathrm{X}$ linked HPRT locus on the lymphocyte. ${ }^{45}$ A significant, dose dependent increase in HPRT mutations was found in a group of patients who received local irradiation for tumour treatment ${ }^{6}$ and also in a group of men environmentally exposed to radon. ${ }^{7}$ A study of atomic bomb survivors assayed 43 years after exposure showed a small but significant increase in HPRT mutation rates. ${ }^{89}$

The GPA assay measures mutation rates of the genes coding for the $\mathrm{M}$ or $\mathrm{N}$ blood group antigens on the surface of red cells. Glycophorin A is the main glycoprotein found in the red cell membrane. In the presence of certain mutagens, the gene code responsible for the production of glycophorin can mutate with no selection disadvantage to the red cell produced. The mutations are of two types, hemizygous (NO) and homozygous (NN). Like the HPRT assay the GPA assay has been used in atomic bomb survivors to analyse mutation rates. ${ }^{1011}$ These studies show a dose dependent increase in mutations 40 years after exposure, which is strong evidence that the mutational lesions are stably integrated into stem cells. In Chernobyl workers a similar dose response was seen. ${ }^{12}$ To our knowledge, there have been no previous reports of HPRT or GPA mutations in underground miners whose environmental exposure to ionising radiation is due principally to the short lived $\alpha$ emitting decay products of radon (radon progeny).

Materials and methods

STUDY POPULATION

The Radium Hill mine was an underground 
uranium mine in the mid-north of South Australia which supplied ore to the United States Atomic Energy Commission and the United Kingdom Government between 1954 and 1961. Pay records held by the South Australian Department of Mines indicate that 2574 workers were employed over the life of the mine. ${ }^{13}$ The mine used the standard ventilation techniques available for underground mines at the time and as a consequence, compared with most modern underground mines, its workers were exposed to relatively high levels of radon and its progeny (mean (range) exposure $8(0-122)$ working level months (WLM)). Follow up of these workers to the end of 1987 showed that lung cancer death rates were higher than expected compared with national mortality rates, and within the cohort lung cancer mortality increased with cumulative exposure to radon progeny. ${ }^{13}$

A sample of the workers who participated in the mortality follow up study were invited to take part in the current study and a total of 253 men agreed. The men in this sample were selected principally because of their proximity to the laboratory (it was necessary that they were living in metropolitan Adelaide), as the assays required relatively rapid processing after venesection. Also the subjects needed to be fit enough to respond to questions concerning their occupational and medical histories, and willing to donate venous blood for the project. In all, $92 \%$ of those contacted agreed to participate in the study. Reasons given for a failure to participate included too difficult (1), too old to participate (1), demented (2), unwilling to give blood (3), not there long enough (1), unwilling but no reason given (7), and refusal by a relative (2).

\section{QUESTIONNAIRE}

A questionnaire was given by trained interviewers to gather information on variables which were considered to be possible confounders of the relation between radiation exposure and somatic mutation rates. The factors considered included age, cigarette smoking, other radiation exposures, exposure to other potential mutagens, medical history, alcohol history, and hobbies. Sex was not considered as all subjects were men.

\section{EXPOSURE ESTIMATES}

Radiation exposure estimates were calculated by converting measurements of concentrations of radon to radon decay products with information available on mine ventilation. In all 721 measurements of radon concentration were made in the mine between 1954 and 1961. At the start of mining, there was only natural ventilation (estimated at $2 \mathrm{~m}^{3} / \mathrm{s}$ ) which was boosted to $5 \mathrm{~m}^{3} / \mathrm{s}$ in mid-1954 with the installation of a Venturi fan. In March 1955, a main fan was installed, increasing the ventilation to about $45 \mathrm{~m}^{3} / \mathrm{s}$. For the period January 1954 to March 1955 the radon monitoring results were averaged for each level of the mine. A mean air residence time was calculated from the mine void and ventilation rate. This was used to calculate the equilibrium fac- tor to convert concentration of radon to concentration of radon-11 decay product. Thus concentrations of radon decay product were estimated for each level of the mine.

After the main fan was installed, there were sufficient radon monitoring results to allow an estimate of the radon concentrations in three regions of the mine (drives, stopes, and the area of the main shaft), as well as the mean concentration on each level. A mine ventilation model was developed with information on contemporary practices and recollections of the workers from the mine. The ages of air in drives and stopes of other levels were estimated by interpolation, and concentrations of radon decay product were estimated with equilibrium factors derived as above. The result of these calculations was a matrix showing for each year, the estimated concentrations of radon decay products for each level and for stopes, drives, and main shaft regions on each level.

Exposures of miners were estimated in the following way. For each of the job categories listed in the employment records, an estimate was made of the proportion of time that would be spent in each of the three regions (shaft, drive, stope). Mining plans were then examined to find in which years appreciable mining was undertaken on each level. An estimate was made of the proportion of time that each category of worker would spend on each level in each region. These proportions were multiplied by the estimated concentrations of radon decay product for that level and region. The sum of these products gave the mean concentrations of radon decay product to which that job category was exposed in that year. Each individual worker's exposure was computed from the employment record. The duration of employment in each job category was calculated and then multiplied by the appropriate concentration of radon decay product from the exposure matrix. Zero exposure was assigned to all surface work. Cumulative exposures then were computed by adding the men's exposures throughout their employment period. Also, verbal estimates of time worked underground by the men themselves were collected as an alternative estimate of exposure.

After the interview, $20 \mathrm{ml}$ of venous blood was taken from the cubital fossa of each participant by a standard technique including a tourniquet. The blood samples were labelled, placed in an insulated container (kept at room temperature), and transferred immediately for processing. To test for variation within each man and to test assay reliability 34 participants had their tests repeated on a separate occasion.

\section{LABORATORY METHODS}

Glycophorin $A$ assay

Detection of variant erythrocytes was performed with the previously published BR6 glycophorin A assay of Langlois et al. ${ }^{14}$ The red cells were sphered immediately and were analysed the next day. Fluorescently labelled monoclonal antibodies were used to see the $M$ and $\mathrm{N}$ antigens of the $\mathrm{MN}$ blood group. The 

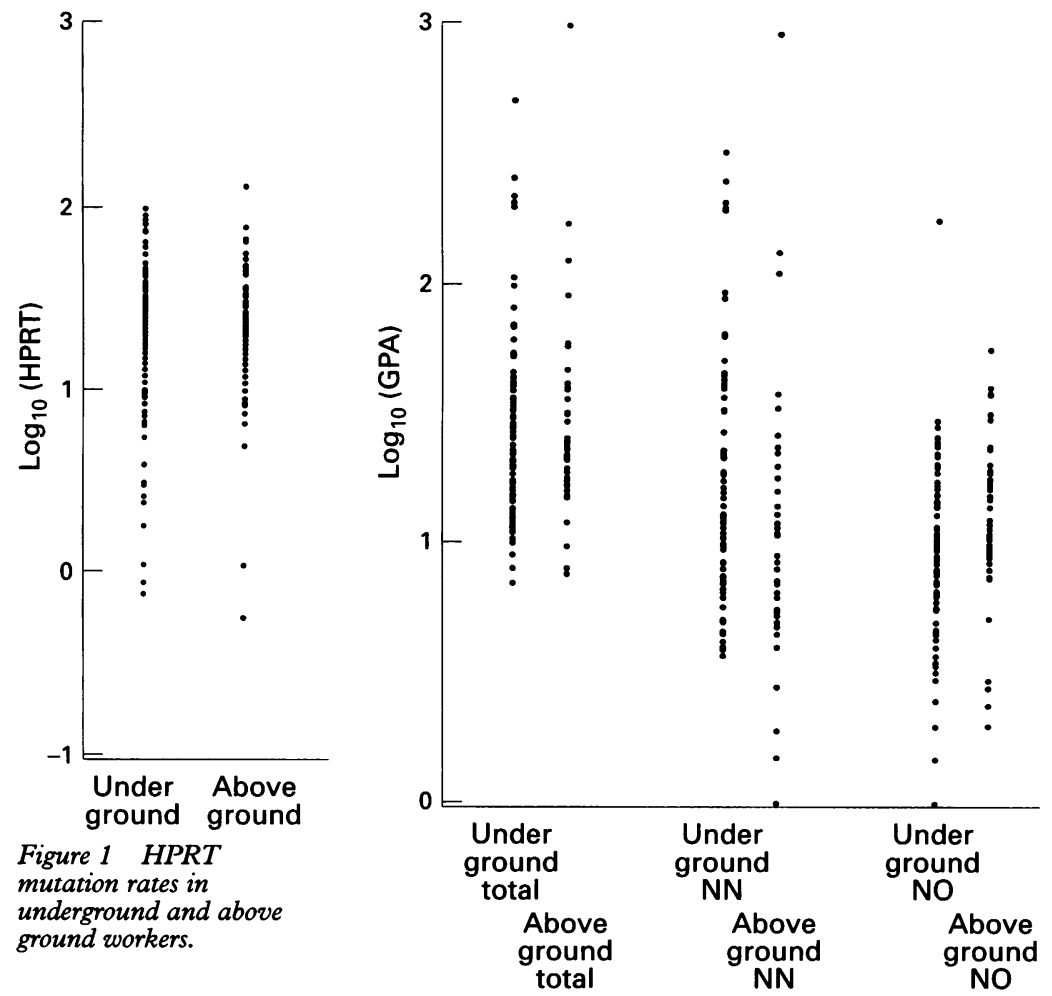

Figure 2 GPA mutation rates in underground and above ground workers.

number of $\mathrm{NO}$ and $\mathrm{NN}$ mutants in $\mathrm{MN}$ men was assessed with a flow cytometer. The monoclonal antibodies used in the assay have been described previously. ${ }^{1516}$ Flow cytometric analysis of the labelled samples was performed on a FACScan single laser flow cytometer with the consort-30 software analysis package (Becton Dickinson Immunocytometry Systems, Mountain View, California).

Table 1 Mean (95\% CI) mutation rates in underground and above ground workers at Radium Hill

\begin{tabular}{|c|c|c|c|c|}
\hline & $\begin{array}{l}\log H P R T \\
\text { mutation rate }\end{array}$ & $\begin{array}{l}\log G P A \\
\text { (total) } \\
\text { mutation rate }\end{array}$ & $\begin{array}{l}\log G P A \\
(N N) \\
\text { mutation rate }\end{array}$ & $\begin{array}{l}\log G P A \\
\text { (NO) } \\
\text { mutation rate }\end{array}$ \\
\hline Above ground workers & $\begin{array}{l}1.29(\mathrm{n}=88) \\
(1.21 \text { to } 1.36)\end{array}$ & $\begin{array}{l}1.39(\mathrm{n}=46) \\
(1.28 \text { to } 1.49)\end{array}$ & $\begin{array}{l}0.93(\mathrm{n}=46) \\
(0.79 \text { to } 1.06)\end{array}$ & $\begin{array}{l}1.13(\mathrm{n}=46) \\
(1.02 \text { to } 1.22)\end{array}$ \\
\hline Underground workers & $\begin{array}{l}1 \cdot 23(n=134) \\
(1 \cdot 17 \text { to } 1 \cdot 29)\end{array}$ & $\begin{array}{l}1.48(n=79) \\
(1.39 \text { to } 1.55)\end{array}$ & $\begin{array}{l}1.23(n=79) \\
(1.13 \text { to } 1.33)\end{array}$ & $\begin{array}{l}0.911(\mathrm{n}=79) \\
(0.83 \text { to } 0.98)\end{array}$ \\
\hline$P$ value & $0 \cdot 223$ & $0 \cdot 11$ & 0.0006 & 0.0011 \\
\hline
\end{tabular}

Table 2 Mean (95\% CI) mutation rates of HPRT and GPA and exposure to radon progeny at Radium Hill

\begin{tabular}{|c|c|c|c|c|}
\hline $\begin{array}{l}\text { Exposure } \\
\text { catagory }\end{array}$ & $\begin{array}{l}\text { Log HPRT } \\
\text { mutation rate }\end{array}$ & $\begin{array}{l}\log G P A \\
\text { (total) } \\
\text { mutation rate }\end{array}$ & $\begin{array}{l}\log G P A \\
(N N) \\
\text { mutation rate }\end{array}$ & $\begin{array}{l}\log G P A \\
\text { (NO) } \\
\text { mutation rate }\end{array}$ \\
\hline$<0.1$ WLM & $\begin{array}{l}1.29(\mathrm{n}=88) \\
(1.22 \text { to } 1.36)\end{array}$ & $\begin{array}{l}1.39(n=46) \\
(1.29 \text { to } 1.49)\end{array}$ & $\begin{array}{l}0.93(n=46) \\
(0.79 \text { to } 1.06)\end{array}$ & $\begin{array}{l}1.12(\mathrm{n}=46) \\
(1.02 \text { to } 1.22)\end{array}$ \\
\hline $0 \cdot 1-5$ WLM & $\begin{array}{l}1 \cdot 18(\mathrm{n}=74) \\
(1 \cdot 10 \text { to } 1 \cdot 26)\end{array}$ & $\begin{array}{l}1.41(\mathrm{n}=46) \\
(1.31 \text { to } 1.52)\end{array}$ & $\begin{array}{l}1.20(\mathrm{n}=46) \\
(1.07 \text { to } 1.34)\end{array}$ & $\begin{array}{l}0.81(\mathrm{n}=46) \\
(0.71 \text { to } 0.91)\end{array}$ \\
\hline 5.1-10 WLM & $\begin{array}{l}1.34(\mathrm{n}=27) \\
(1.26 \text { to } 1.53)\end{array}$ & $\begin{array}{l}1.65(\mathrm{n}=13) \\
(1.46 \text { to } 1.85)\end{array}$ & $\begin{array}{l}1.40(n=13) \\
(1.14 \text { to } 1.65)\end{array}$ & $\begin{array}{l}1.15(n=13) \\
(0.97 \text { to } 1.33)\end{array}$ \\
\hline$>10$ WLM & $\begin{array}{l}1.20(\mathrm{n}=33) \\
(1.08 \text { to } 1.33)\end{array}$ & $\begin{array}{l}1.50(n=20) \\
(1.33 \text { to } 1.65)\end{array}$ & $\begin{array}{l}1.19(\mathrm{n}=20) \\
(0.98 \text { to } 1.39)\end{array}$ & $\begin{array}{l}0.98(n=20) \\
(0.83 \text { to } 1.12)\end{array}$ \\
\hline $\begin{array}{l}P \text { value, test for } \\
\text { linear trend }\end{array}$ & $0 \cdot 74$ & 0.16 & 0.08 & 0.94 \\
\hline
\end{tabular}

HPRT Assay

The HPRT assay was performed on peripheral blood lymphocytes as described previously by Morley et al. ${ }^{17}$ The method is based on the ability of mutated lymphocytes, which are deficient in HPRT, to be able to proliferate in the presence of thioguanine.

\section{STATISTICAL ANALYSIS}

The GPA results were reported as the number of variant cells per million red blood cells. The HPRT assay results were reported as a mutation frequency-that is, the number of clonable cells in the presence of thioguanine divided by the number of clonable cells in the absence of thioguanine. The assay results were logarithmically transformed before application of statistical analyses. Associations between mutation rates and estimated radiation exposures were investigated by analysis of variance. Orthogonal polynomial contrasts were used to test for a linear trend. The possibility of simple non-linear models fitting the data was examined, but none did. Adjustments were made for potential confounders with linear regression and analysis of covariance. The possibility of examining radon exposure as a continuous variable was examined, but this approach was not informative.

Statistical analyses were performed with the SAS/STAT software. ${ }^{18}$ The linear regression analyses of the repeat blood samples were performed with the Instat (GraphPAD software) program.

\section{Results}

We first examined the relation between the mutation rates in those workers exposed to radon (underground workers) versus those not exposed (above ground workers). Underground workers included all who worked underground for some of their time at Radium Hill. Above ground workers included men who only worked on the surface for their time at Radium Hill.

Figure 1 shows the distribution of the data for the HPRT assays in underground and above ground workers. Figure 2 shows the distribution of the glycophorin A assay data.

Table 1 shows the mean ( $95 \%$ confidence interval (95\% CI)) mutation rates in underground and above ground workers at Radium Hill.

Table 2 shows the relation between HPRT and GPA mutation rates and cumulative exposure to radon progeny at Radium Hill, (measured in WLM).

\section{CONFOUNDING VARIABLES}

Of the workers $\mathbf{7 5 \%}$ were either current smokers $(37 \%)$ or ex-smokers $(38 \%)$. The mean (SD) cigarette smoking dose (in cigarettes/day $\times$ years smoked) was 431 (479) for above ground workers $(\mathrm{n}=105)$ and 516 (483) for underground workers $(n=143)$. The difference between cigarette smoking doses between the two groups were not significant $(P=0 \cdot 17)$.

The mean age of the above ground workers 
Table 3 Estimated mean exposures to various confounders $v$ work underground at Radium Hill and estimated dose stratified by WLM

\begin{tabular}{|c|c|c|c|c|c|c|}
\hline & $\begin{array}{l}\text { Mean } \\
\text { age }\end{array}$ & $\begin{array}{l}\text { Cigarette } \\
\text { dose } \\
(p k t / y)\end{array}$ & $\begin{array}{l}\text { Time in } \\
\text { other mines } \\
\text { (month) }\end{array}$ & $\begin{array}{l}x \text { rays to } \\
\text { lumbar } \\
\text { region } \\
n\end{array}$ & $\begin{array}{l}C T \\
\text { scans } \\
n\end{array}$ & $\begin{array}{l}\text { Nuclear } \\
\text { med scans } \\
n\end{array}$ \\
\hline \multicolumn{7}{|l|}{ Worked underground: } \\
\hline yes & $62 \cdot 4$ & $515 \cdot 7$ & $71 \cdot 8$ & $3 \cdot 3$ & $0 \cdot 8$ & $0 \cdot 2$ \\
\hline no & $63 \cdot 3$ & 435 & 36 & 2 & 0.5 & $0 \cdot 3$ \\
\hline \multicolumn{7}{|l|}{ Exposure (WLM): } \\
\hline$<0.1$ & $63 \cdot 3$ & 435 & 36 & 2 & 0.5 & 0.3 \\
\hline $0 \cdot 1-5$ & 62 & $546 \cdot 8$ & $59 \cdot 1$ & $3 \cdot 3$ & 0.7 & $0 \cdot 3$ \\
\hline $5 \cdot 1-10$ & $61 \cdot 7$ & $394 \cdot 4$ & 105.6 & $4 \cdot 2$ & $1 \cdot 2$ & $0 \cdot 2$ \\
\hline$>10$ & 64 & $558 \cdot 6$ & $75 \cdot 2$ & $2 \cdot 7$ & 0.4 & $0 \cdot \overline{2}$ \\
\hline
\end{tabular}

was 63.3 years $(n=105)$, and that for underground workers was $62 \cdot 4$ years $(n=143)$.

Table 3 shows further information on potential confounders.

Few participants reported other potential confounders such as other occupational exposures to radiation or medical conditions involving radiotherapy or chemotherapy. One man had been treated with chemotherapy for cancer, two had received radiotherapy, and 17 men stated that they had worked in jobs which may have resulted in other radiation exposure.

Multivariate analyses were performed to assess any potential combined contribution from confounders including: cigarette smoking, age, alcohol use, $x$ ray films, other mining work, or work where exposure may have occurred, medical conditions where exposure may have occurred, other medical conditions, possible exposure to mutagenic substances in non-occupational environments, history of blood transfusions, and presence at Maralinga (an atomic bomb testing site).

As age and cigarette smoking are thought to be the most important of these variables, an analysis controlling for these two variables was performed (table 4). There was no significant change in the relations of the variables versus

Table 4 Mutation rates in above and underground workers, adjusted for age and cigarette smoking (log mean mutation rates)

\begin{tabular}{lll}
\hline Mutation assay & Above ground workers & Underground workers \\
\hline HPRT & 1.28 & $1.23(\mathrm{P}=0.29)$ \\
GPA (Tot) & 1.38 & $1.47(\mathrm{P}=0 \cdot 19)$ \\
GPA (NN) & 0.92 & $1.23(\mathrm{P}=0.0006)$ \\
GPA (NO) & 1.12 & $0.91(\mathrm{P}=0.18)$ \\
\hline
\end{tabular}

Table 5 Mutation rates in above and underground workers, adjusted for potential confounders using analysis of covariance (log mean mutation rates)

\begin{tabular}{lll}
\hline Mutation assay & Above ground workers & Underground workers \\
\hline HPRT & 1.14 & $1.06(\mathrm{P}=0.13)$ \\
GPA (Tot) & 1.46 & $1.61(\mathrm{P}=0.07)$ \\
GPA (NN) & 1.05 & $1.39(\mathrm{P}=0.0027)$ \\
GPA (NO) & 1.04 & $0.93(\mathrm{P}=0.18)$ \\
\hline
\end{tabular}

Table 6 Comparison data on repeat assays

\begin{tabular}{llll}
\hline Assay & Samples $n$ & $\begin{array}{l}\text { Correlation } \\
\text { coefficient }\end{array}$ & P value \\
\hline HPRT & 19 & 0.29 & $0 \cdot 22$ \\
GPA (Tot) & 34 & 0.93 & $<0.0001$ \\
GPA (NN) & 34 & 0.82 & $<0.0001$ \\
GPA (NO) & 34 & 0.42 & 0.015 \\
\hline
\end{tabular}

exposure. This is not surprising considering the similarities in the two groups in their age and smoking histories.

When the analysis was adjusted for all the confounding variables the GPA (total) and GPA (NN) mutation frequencies were still significantly increased in underground workers but the mean GPA (NO) frequency was not significantly different from that for the control group (table 5).

\section{ANALYSIS OF THE REPEATED SAMPLES}

Repeat assays (34 GPA and 19 HPRT) were performed on second blood samples collected from a subsample of 34 participants. Table 6 shows the results of the comparison of these assays. The GPA assays were highly reproducible but the HPRT assays were not.

\section{Discussion}

This study shows no clear relation between HPRT mutation rates and previous occupational exposure to radon. However there is a significant relation between mutation rates of glycophorin $A$ and the estimates of radon exposure. Higher total mutation rates for glycophorin A were found in underground workers than above ground workers. This pattern is due chiefly to an increase in NN type mutations. There is a tendency for glycophorin A total mutations to increase with exposure up to the highest exposure category (>10 WLM). This trend is not significant and is mainly due to the contribution of the homozygous type.

There is an increase in the homozygous mutation type with increasing dose, with a flattening at the highest exposure category (greater than 10 WLM).

Adjustment for an extensive list of possible confounders did not alter the results in any substantial way. It strengthened the evidence of increased GPA total and NN mutation in underground workers (table 5) and it also caused the NO mutation result to be no longer notably at odds with our hypothesis. This suggests that the unexpectedly negative result in the unadjusted data (table 1) may have at least in part been due to confounding factors.

There are several strengths in this particular study. Firstly, the work is human based research performed on a cohort of workers in the type of situation where such assays may find application in the future. Secondly, unlike many other studies involving historical exposures, detailed estimates of personal exposures were available. The exposure estimates have previously been correlated with increased rates of lung cancer deaths in this cohort, which increases their credibility. ${ }^{13} \mathrm{~A}$ further strength of the study is the internal control group (above ground workers) which reduces the likely influence of confounding factors. The most important of the confounders is age, but other important variables include sex, cigarette smoking, alcohol history, occupational histories, and medical histories.

The assays were all performed at a single laboratory by staff well trained in the processes. The high correlation found in the 
repeat specimens in the glycophorin assays is further evidence of the quality of the laboratory procedure. The repeat HPRT assays did not show as close a correlation as the glycophorin assay, but this would be expected from the statistics of the two assays. A typical glycophorin assay scores three to 10 more mutational events than a typical HPRT assay, and this factor alone would lead to the coefficient of variation for the HPRT assay being 1.7-3.2 times that of the glycophorin assay.

The ages of cohort members means there will be opportunity in the short to medium term to relate disease outcome to mutation results. This work could then contribute to our knowledge of biomarkers of effect. The relatively low exposure to radon progeny at Radium Hill (compared with other uranium mines of the time) may limit the ability of the study to detect increased levels of mutations, but the circumstances of the Radium Hill miners relate more directly to modern day exposures than most previous cohorts of underground miners.

The finding that the HPRT assay did not detect an effect of radiation exposure is an apparent contradiction both to previous findings by other workers ${ }^{6-9}$ and to our present findings of an increase in glycophorin $\mathrm{NN}$ mutations. Factors in the present study which might explain failure to detect an effect are: a low absolute exposure at Radium Hill; a low dose rate at Radium Hill; and the 30 years which elapsed between exposure and study as there is evidence that the HPRT mutations are selected against in vivo. ${ }^{19}$ Our findings of HPRT and glycophorin mutations are, in fact, internally consistent rather than contradictory. Glycophorin NN mutations, the type found to be increased, are thought to result from chromosomal mechanisms such as mitotic recombination and such mechanisms are not detectable by the HPRT assay as the HPRT locus is situated on the $\mathrm{X}$ chromosome. Glycophorin NO mutations are thought to be due to point mutation or deletion, the same mutational mechanisms as detected by the HPRT assay and they were likewise not detectably increased. There are other possibilities. Obviously, there may not have been an association in reality or the association may have been so small as to be not detectable by our assay.

The glycophorin mutations detected in circulating erythrocytes must have reflected mutational events in the stem cells of the bone marrow. The mechanism by which the red cell precursors are irradiated by inhaled radon progeny is thought to be through absorption into the bloodstream. ${ }^{20}$ Radon and its progeny are relatively fat soluble and absorption into the fat cells of the marrow is thought to be the possible explanation for increases reported in rates of myeloid leukaemia in areas of high domestic radon. ${ }^{21}$

The application of biomarkers in occupational health practice faces considerable technical, legal, and ethical difficulties. Biomarkers of effect are especially contentious when the outcome is a malignancy (such as lung cancer) which responds poorly to treatment. In these circumstances the use of somatic mutations in a clinical setting clearly may do more harm than good unless it is possible to identify a subgroup of affected workers whose cancers are unusually susceptible to treatment. This study suggests that there may be a relation between occupational exposures to radon progeny and long lasting increases in some somatic mutations. However, our current knowledge is far short of providing a useful tool for screening workforces such as underground miners. Further work in this area will hopefully enlarge understanding of the biological effects of ionising radiation and point the way towards better estimates of the radiation doses received by workers. The value of this work must be balanced against the psychological morbidity that may be imposed on people who are told that their mutation rates are high.

We thank Dr Phil Crouch from the SA Health Commission for the calculation of the radiation exposure estimates, Kristyn Willson for her valuable statistical advice, Marg Lee for undertaking much of the field work, and Tania Siviour for her technical assistance. The SA Mining and Quarrying Fund for partial funding of this research.

1 Perera F. Molecular cancer epidemiology: a new tool in cancer prevention $\mathcal{f}$ Natl Cancer Inst 1987;78: 887-98.

2 Mendelsohn ML. New approaches for biological monitoring of radiation workers. Health Phys 1990;59:23-8.

3 Morley AA. Human somatic mutations-where are we going? In: Mendelsohn M, Albertini RJ, eds. Mutation and the environment part $C$. somatic and hertiable mutation adduction, and epidemiology. New York: Wiley-Liss, 1990:1-5.

4 Albertini RJ, Castle KL, Borcherding WR. T-cell cloning to detect the mutant 6-thioguanine-resistant lymphocytes present in human peripheral blood. Proc Natl Acad Sci USA 1982;79:6617-21

5 Morley AA, Trainor KJ, Seshardri RS, Ryall RG. Measurement of in vivo mutations in human lymphocytes. Nature 1983;302:155-6.

6 Messing $\mathrm{K}$, Seifert AM, Bardley WEC. In vivo mutant frequency of patients exposed to ionizing radiation. 4th International Congress on Environmental Mutagenesis. Stockholm: 1985:65.

7 Bridges BA, Cole J, Arlett CF, Green $\mathrm{MH}$, Waugh AP, Beare $\mathrm{D}$, et al. Possible association between mutant frequency in peripheral lymphocytes and domestic radon quency in peripheral lymphocytes and

8 Hakoda M, Akiyama M, Kyoizumi S, Awa A, Yamikido M, Otake $M$. Increased somatic cell mutant frequency in Otake $M$. Increased somatic cell mutant frequency
atomic bomb survivors. Mutat Res 1988;201:38-48.

9 Akiyama M, Kyoizumi L, Hirai Y, Hakoda M, Nakamura N, Awa A. Studies on chromosome aberrations and HPRT mutations in lymphocytes and GPA mutations in erythrocytes of atomic bomb survivors. In: Mendelsohn M, Albertini RJ, eds. Mutation and the environment, part $C$ : hertiable mutation, adduction, and epidemiology. New York: Wiley Liss, 1990:68-80.

10 Langlois RG, Bigbee WL, Kyoizumi S, Bean M, Akiyama $M$, Nakamura $N$, Jensen $R$. Evidence for increased somatic cell mutation of the glycophorin A locus in atomic bomb survivors. Science 1987;236:445-8.

11 Kyoizumi S, Nakamura N, Hakoda M, Awa AA, Bean MA, Jensen R, Akiayama M. Detection of somatic mutations at the glycophorin A locus in erythrocytes of atomic at the glycophorin A locus in erythrocytes of atomic 49:581-8.

12 Langlois RG, Bigbee WL, Jensen RH. The glycophorin A assay for somatic cell mutations in humans. In: Mendelsohn M, Albertini RJ, eds. Mutation and the environment part C: somatic and hertiable mutation, adduction, and epidemiology. New York: Wiley-Liss, 1990: 47-56.

13 Woodward A, Roder D, McMichael AJ, Crouch P, Mylvaganam A. Radon daughter exposures at the Radium Hill uranium mine and lung cancer rates among former workers, 1952-87. Cancer Causes Control 1991; 2:213-20.

14 Langlois RG, Nisbet BA, Bigbee WL, Ridinger DN, Jensen RH. An improved flow cytometry assay for somatic mutations at the glycophorin A locus in humans. mutations at the glycoph

15 Bigbee WL, Vanderlaan $M$, Fong SS, Jensen $R H$. Monoclonal antibodies specific for the $M-$ and $N$ - forms of human glycophorin A. Mol Immunol 1983;20: of hum
$1353-62$.

16 Langlois RG, Bigbee WL, Jensen RH. Flow cytometric characterization of normal and variant cells with mono- 
clonal antibodies specific for glycophorin. Am $\mathcal{f}$ Immunol 1985;134:4009-17.

17 Morley AA, Trainor, KJ, Dempsey JL, Seshardri RS. Methods for study of mutations and mutagenesis in human lymphocytes. Mutat Res 1985;147:363-7.

18 SAS Institute. SAS/STAT guide for personal computers, version 6. Cary, North Carolina: SAS Institute, 1987.

19 Dempsey JL, Morley AA, Seshardri RS, Emmerson B, Gordon R, Bhagat C. Detection of the carrier state for an X-linked disorder, the Lesch-Nyhan syndrome, by the use of lymphocyte cloning. Hum Genet 1983;64: 288-90.

20 Richardson RB, Eatough JP, Henshaw DL, Dose to red bone marrow from natural radon and thoron exposure. Br f Radiol 1991;64:608-24.

21 Henshaw DL, Eatough JP, Richardson RB, Radon as a causative factor in induction of myeloid leukaemia and other cancers. Lancet 1990;335:1008-12.

\section{Occupational and Environmental Medicine and the electronic age}

OEM has an Email address which is 100632.3615@compuserve.com.We welcome contact by Email, including letters to the editor. Some of our reviewers already send us their reports by Email, helping to speed up the peer review process.

We are moving towards electronic publishing and for some months now we have been asking authors to send us their revised papers on disk as well as a hard copy. I am delighted to report that nearly all our authors are managing to comply with this request; far more than for other specialist journals in the BMJ Publishing group. Oddly enough, the few authors who have not sent us a disk version of their revised papers have been almost exclusively from the United Kingdom. I would be interested in suggestions for why this might be. Perhaps United Kingdom based authors read our correspondence and instructions less assiduously? Watch for revised Instructions to Authors.

The Editor 